\title{
Spatial imaginaries and collective identity in women's human rights struggles in Honduras
}

\author{
Maaret Jokela-Pansini \\ Institute of Geography, Cultural Geography Research Unit, University of Bern \\ Hallerstrasse 12, 3012 Bern, Switzerland \\ maaret.jokela@giub.unibe.ch
}

\begin{abstract}
In recent years, geographic analysis on social movements has emphasised the influence of actors' concepts, lived experiences, and perceptions of space on the emergence of collective action. Cultural approaches to social movements in Latin America as well as feminist scholarship have revealed that women's collective action is shaped by their perceptions of institutional and societal challenges, which are rooted in authoritarian and patriarchal culture prevalent in their society. This article combines geographic and cultural approaches to social movements as well as transnational feminist theories to explore women's human rights mobilisation in Honduras after the coup d'état in 2009. It investigates how a group of urban and rural activists that included feminists, rural women, students and community leaders, adopted human rights discourses and practices to respond to the coup. The article draws on interviews and focus group discussions to suggest firstly, that protests in response to the coup shaped the interviewees' spatial imaginaries and particularly considers how urban feminists' spatial imaginaries were merged with those of rural women under the collective framework of human rights. Secondly, the study demonstrates that a collective identity as women human rights defenders was crucial for the emergence of collective action and also prompted the establishment of a national network. This case study contributes to research on women's collective action to negotiate women's rights, human rights and social justice in changing political processes.
\end{abstract}

Keywords: women's movements; gender; collective identity; coup d'état; Honduras 
A new political space is designed beyond the traditional distinction between state and 'civil society': an intermediate public space, whose function is not to institutionalise the movements nor to transform them into parties, but to make society hear their messages and translate these messages into political decision making, while the movements maintain their autonomy (Melucci, 1985, p. 815).

A large body of research has brought to light the various strategies that women's movements, ${ }^{1}$ particularly feminist movements, have adopted to negotiate spaces in changing political processes, including in Latin America (Espina, 2009; Jaquette, 2001; Vargas, 2001). For example, women's- and feminists' collective mobilisation in the era of authoritarian regimes in the 1970s and 1980s and later in democratic transition processes in the region have been well documented (S. E. Alvarez, 1990; Chinchilla, 1994; Noonan, 1995). Empirical analysis indicates that such mobilisation has emerged on the basis of multiple collective identities, including gender. Baldez (2003) has argued in a comparative study that existing resources, the exclusion of women from agenda-setting processes within the opposition, and the way issues are framed influence women's mobilisation based on gender identity.

However, there is hardly any empirical evidence on women's collective human rights mobilisation in the $21^{\text {st }}$ century in Latin America. Moreover, research generally focuses on countries in South America and largely ignores case studies in Central America, including Honduras (for exceptions see Brondo, 2007; Mollett, 2010; Sundberg, 2004). The present study seeks to fill this research gap by exploring first, how a group of activists combined various understandings of space or, spatial imaginaries (Wolford 2004), which are here understood as collective and individual cognitive frameworks, constructed through activists' perceptions and lived experiences of space. I argue that these spatial imaginaries were shaped by the institutional and societal challenges women experienced due to the coup and their responses to them. 
The study discusses how urban feminists' spatial imaginaries were united with those of rural women under the collective framework of human rights. The study's second aim is to analyse how the collective identity as women human rights defenders emerged during the protests and prompted the establishment of a national network. I argue that this case study deepens our understanding of the crucial role women's movements play in changing political processes. As Merry and Levitt (2010) have previously stated, this type of analysis can also reveal the significance and challenges of the human rights framework for women's movements that simultaneously organise for both women's rights and for social justice.

On 28 June 2009, military forces and their political allies ousted President Manuel Zelaya from office on the day of a referendum that would have enabled the governing regime to enforce changes in the constitutional charter. Honduras had struggled with human rights violations for decades but violence reportedly increased in the aftermath of the coup d'état, affecting particularly journalists and human rights defenders (UNHRC, 2012). International organisations, such as the United Nations, have labelled Honduras the most dangerous country in the world due to its excessive homicide rate per capita: In this country of 8.5 million inhabitants 90.4 violent homicides were reported per 100000 people in 2012 (UNODC, 2013). A significant part of this violence in Honduras and the other countries in the Northern Triangle of Central America derives from drug trafficking, organised crime and gang violence (Arnson \& Olson, 2011; Brenneman, 2014). These reports show that atrocities particularly against women have increased.

Political and economic instability, culminating in the coup d'état led to extensive protests and mobilised various actors in civil society (see also Sosa Iglesias, 2014). A group of feminists, students, rural women and community leaders, among 
others, formed a joint coalition, Feministas en Resistencia (FER) ${ }^{2}$ (see also Ronderos, 2011). They increasingly embedded the notion of human rights in their claims while continuing to promote equal rights and to stand against militarisation, neo-liberal policies and weak democratic systems. These women activists met challenges collectively as defensoras de los derechos humanos, women human rights defenders. The term, commonly used in the international community, refers to women who individually or together act in defence of women's human rights as well as the full range of rights, whether civil, political, economic, social, cultural, environmental, sexual, or reproductive (IM Defensoras, 2015).

While this article examines women human rights defenders it acknowledges the large body of theoretical and empirical feminist work (including Alexander \& Mohanty, 1997; S. E. Alvarez, 2000; Basu, 2000; McCall, 2005; B. Mendoza, 2002; Mohanty, 2003b; Mollett \& Faria, 2013; Sundberg, 2004; Wright, 1997), that highlights the intersectionality of women's lived experiences regarding class, age, race, ethnicity, sexuality, and religion as well as urban and rural differences. As McCall (2005, p. 1781) notes, studying this number of analytical categories is, however, complex; intersectional analysis is able to situate subjects only from a partial perspective of the social group under study. In my analysis, I chose gender and places as 'anchor points' (Glenn, 2002 in McCall 2005) because the two categories reflect the interviewees' own discourses. My analysis therefore concentrates on spatial imaginaries of activists from urban feminist organisations and rural women's organisations.

The next section presents the methodology of this study, followed by an overview of spatial and cultural approaches to social movements as well as transnational feminist theories on women's collective activism. I then outline the literature on women's collective human rights framing and women's human rights 
activism in Latin America and its precursors in Honduras. The last two sections discuss first how the aftermath of the coup shaped activists' spatial imaginaries and then, how the collective identity as women human rights defenders emerged.

\section{Methodology}

I worked from September 2008 to June 2009 with local feminist and women's organisations in Tegucigalpa and its surroundings. This provided extensive background material and helped me identify interview partners for this study.

I conducted fieldwork for four months in 2013. During the first field visit in January-February 2013 my objective was to understand women's collective responses to the coup. I thus interviewed women previously engaged in Feministas en Resistencia and other key actors connected with the protests. Many interviewees referred to human rights and to the term 'women human rights defenders', which is why I focused on the use of human rights discourses during my second field visit in September-December 2013.

I discussed the research with activists during the whole research process, which helped to identify topics grounded in the local political and social context. This is an important aspect of feminist ethnographic methodology (Naples, 2003; Okazawa-Rey, 2009), which aims to engage in intellectual and political struggles that address and seek to transform gendered power relations and to reconstruct theory and method (Staheli \& Lawson, 1995).

Feminist geographic analysis emphasises that women's narratives are crucial for understanding identity-building processes among activists (Pratt, 2000; Wright, 2004). This study therefore draws on qualitative data that includes semi-structured interviews, focus group discussions and participant observation conducted in Tegucigalpa, San Pedro Sula, La Esperanza and Siquatepeque. The interviewees, between 19 and 73 years 
old, were comprised of 38 community leaders, representatives of non-governmental organisations, women's municipal offices and ministries and, were directly or indirectly linked with the Network of Women Human Rights Defenders. ${ }^{3}$ This network is an umbrella organisation whose members -40 at the time of the interviews - are individuals and activists from feminist organisations, feminist university associations, rural indigenous movements, trade unions and women's community-based networks in both urban and rural areas.

I participated in various meetings, workshops, and conferences organised on women's and human rights, which enabled me to identify interviewees at these events. The interviewees were selected through snowball sampling (Atkinson \& Flint, 2001). My fieldwork ended after the national elections in December 2013, which marked the end of the post-coup government's first legislative period. This government was the main adversary of women activists in the aftermath of the coup.

The conversations were recorded and transcribed into English and then transferred into the qualitative text-analysis software MAXQDA. The interviews were first coded and then the main themes characterised according to women's narratives of their struggles including challenges, alliances and perceptions on women's collective action after the coup. These yielded different spatialities of struggle concerning contexts such as women's rights, land rights, human rights as well as political rights but also scales, including the national, regional and international. I interpreted the interview material according to critical discourse analysis, which recognises that discourse 'constitutes situations, objects of knowledge, and the social identities of and relationships between people and groups of people' (Fairglough \& Wodak, 1997, p. 258). It aims to investigate these social identities and relationships and the connection between language and power (Wodak, 2001). 
The analysis of these discourses yielded two analytical categories. The first, spatial imaginaries, derived from interviewees' perceptions and lived experiences on their struggles. The second, collective identity as women human rights defenders, was introduced by the interviewees themselves to characterise their activism.

Feminist ethnographic research seeks to understand not only interactions between actors but also the ways the relationship between the researcher and the researched shape the questions (see also Naples, 2003; Sundberg, 2004). Other social identities also impact the research process. For example as a woman, interviewing women on their identity influences the interviewees' narratives of their own identities. During my research, I needed to acknowledge that my position as a researcher became entwined with my previous position as a colleague. Here, snowball sampling was useful because it facilitated the interaction with 'new' individuals and organisations, including government representatives and local women's organisations.

\section{Conceptualising women's (intersectional) collective action: Cultural and spatial approaches to social movements}

Scholars in social movement studies have largely analysed changes in political processes. They have found that such processes can largely shape and contribute to the emergence of collective action and, both restrict and open opportunities for activists (Kriesi, 2007; McAdam et al., 1996; Meyer \& Staggenborg, 1996; Tilly, 2004, Jaquette 2009). While theories on political processes partly explain the emergence of collective action in political upheavals, they do not fully explain how different actors organise collectively. I argue that drawing on spatial and cultural approaches to social movements as well as on transnational feminist theories on women's collective action helps to analyse how women across different social identities organised themselves using a gender identity after the coup. 
Research on the spatialities of social movements has explored how the notions of space, place, and scale affect collective action and opportunities as well as the ways activists shape, perceive, and act upon these opportunities (Escobar, 1998; Martin \& Miller, 2003). These studies have followed the prevalent notion in geography that space is always socially constructed and influences the process of collective action (Lefebvre, 1991). Massey (1994) and Wolford (2004), however, have argued that research should seek to understand the equally important spatial constitution of the social instead of focusing on the social construction of space. Wolford states that movements are constructed through 'spatial imaginaries', which are 'the cognitive frameworks, both collective and individual, constituted through the lived experiences, perceptions, and conceptions of space itself' (Lefebvre, 1991 in Wolford 2004, 411). She demonstrates in her work on land struggles in Brazil how two movements formed their resistance based on different spatial imaginaries. Such spatial imaginaries are an important discursive element in constructing frameworks because they form a common basis for movements against 'outside' forces (Nicholls 2007) and shape individuals' decision to adopt certain strategies as well as find commonalities in struggles (Holloway \& Pelaez, 1998; Sundberg, 2007).

This study draws on Wolford's notion on spatial imaginaries and regards space as the object of mobilisation, which is constituted of different lived experiences and perceptions of space. Feminists' campaigning in urban areas, women's networks' struggles for their rights in their communities or land struggles in rural areas all shape and constitute women's different understandings of space. Examining women's collective action through the notion of spatial imaginaries - rather than simply the notions 'spaces' or 'social movements' - helps to explore how the women interviewed experienced the societal and institutional challenges after the coup and began 
identifying themselves as women human rights defenders. I argue that this concept also facilitates the analysis of actors with different intersectional identities because it concentrates on women's lived experiences and perceptions.

Latin American scholarship (Alvarez et al., 1998) has highlighted the social and cultural notions of social movements. These studies have found that social movements challenge hierarchies constituted by the state but also those constructed by the society and the authoritarian culture prevalent in the society. Moreover, social identities such as gender, class and race constitute 'different categories of people hierarchically disposed in their respective 'places' in society' (Dagnino, 1998; see also Coe, 2015). Cultural approaches in social movement studies in general address collective identities, cultures and emotions and draw on meaning rather than rational action (Escobar, 2001; Jasper, 2014; Melucci, 1985; Polletta \& Jasper, 2001). Collective identity is here defined as the ground for collective action and as

[...] an individual's cognitive, moral, and emotional connection with a broader community, category, practice, or institution [...] a perception of a shared status or relation, which may be imagined rather than experienced directly, [...] distinct from personal identities, although it may form part of a personal identity essential for social movements (Polletta \& Jasper, 2001, p. 285).

Some scholars have argued that collective identities and emotions are even necessary for the sustainability of protest over longer periods: The Madres de Plaza de Mayo initially organised to draw attention to their lost relatives during the authoritarian regime in Argentina but have maintained continuity over 30 years partly through their collective identity as mothers (Bosco, 2006). Collective identity, however, is not 'given' but constructed through a complex system of negotiations, exchanges, and decisions (Melucci, 1985). Alvarez (2000) has studied women's negotiations in Latin America and pointed how actors mobilise beyond the local context in order to (re)construct or 
restate subaltern or politically marginalised collective identities and to establish alliances with others.

Feminist scholars in both the global North and global South have emphasised that questions of political consciousness and identity are crucial aspects of women's activism (Mohanty, 2003a; Rupp \& Taylor, 1999; Staggenborg, 1998, 2001; Taylor \& Whittier, 1992; see also Wright, 2005 Brown \& Staeheli, 2003; Mollett, 2010 in this journal).

Feminist scholars including Mohanty have in the past decade called for a transnational feminist practice and urged to 'build[ing] feminist solidarities across the divisions of place, identity, class, work, belief and so on' (2003a, p. 250) rather than emphasising difference. In this regard, numerous empirical studies have shown that feminist ideologies are crucial for the construction of strong networks and women's movements (Hassim, 2006; Jaquette, 2001; Molyneux, 1998). Others have argued that feminism in the $21^{\text {st }}$ century in Latin America has spread beyond feminist organisations and horizontally into different racial-ethnic communities and social and cultural arenas, intersecting with other social movements (Alvarez 2014). According to di Marco this is because 'carriers of traditional and patriarchal values' have presented a common adversary for feminists and other movements, which has given rise to a collective identity as 'feminist people' (Di Marco 2006 in Alvarez 2014). Indigenous, Afrodescendants, workers and lesbians, whom feminists in the 1990s saw as 'others', have transformed feminist ideas and created 'other feminisms' (Alvarez 2014).

However, the construction of solidarities and identities within networks is challenging because they are contested and multiple and involve antagonisms (see e.g. Routledge, 2009). Some scholars have argued that human rights discourses can assist 
particularly women's movements because these are accessible to a wide range of actors and identities (Merry, 2006b).

\section{The human rights framework and women's collective action based on gender}

Scholars in human geography, anthropology, law and political sciences have found that women's movements have successfully used human rights framing in different geographic and political contexts. The human rights framework has therefore become an element particularly of women's social justice movements worldwide (Keck \& Sikkink, 1998; Merry, 2006b). It helps women activists 'translate' their claims to an international scale and gain visibility for their grievances. As Merry (2006a) has stated:

\footnotetext{
Local human rights activism lies at the conjunction of particular local grievances and transnational social movements and depends on intermediaries with multiple conciousnesses to translate back and forth between them. The human rights frame takes a particular story and makes it general, targeting the state as the responsible agent and source of redress. [...] But an individual story becomes politically efficacious only when it is attached to a larger principle that provides a basis for making alliances and building coalitions. As the local story is inserted into a more general one, it generates support outside the local community (p. 216).
}

More than a legal instrument for the protection of rights, human rights framing can also contribute to the culture of social movements in multidimensional ways (Keck \& Sikkink, 1998, Alvarez 2000). The highly contested nature of the human rights discourse, however, can make such a strategy particularly challenging for women. This is because women who promote human rights are often perceived as challenging existing gender roles and socio-cultural norms and traditions in their societies (UNHRC, 2010). Moreover, women human rights activists experience gender-based violence including rape, physical and verbal abuse as well as persecution (IM-Defensoras 2014). 
Often, women's human rights agency not only shapes the culture of the women's movement but also contributes to the consciousness of gender roles in the society and the recognition of women as political actors (Keck \& Sikkink, 1998). In response to development approaches to gender, transnational feminist scholars have highlighted the importance of women's agency rather than presenting women as victims (Alexander \& Mohanty, 1997). Alexander and Mohanty define women's agency as 'the conscious and ongoing reproduction of the terms of one's existence while taking responsibility for this process' and as 'thinking of oneself as part of feminist collectivities and organisations' (Alexander \& Mohanty, 1997, p. xxvii).

Finally, as a 'voice and conscience of civil society' human rights defenders play an important role not only locally but also in the international human rights regime since they can draw on international legal frameworks to address their government's human rights violations (Brysk, 2014, p. 342). The adoption of the term 'human rights defenders' itself provides an international legal framework and potentially contributes to the protection of human rights activists.

\section{Precursors of women's human rights activism in Latin America and Honduras}

Jelin (1994) identifies two parallel notions of women's human rights activism in the Latin American region. The first consists of women's struggles for liberty, women's rights, and feminist ideologies. The second draws on women's engagement in promoting human rights and fostering women's role as developers and implementers of demands in local and transnational spaces as well as defenders of human rights.

Across the region, women's movements were central actors in claiming rights in both these ways during democratic transitions, civil wars, and peace processes in the 1980s and 1990s (Jaquette, 2009). Initially, women's human rights activism in this 
period was largely related to women's personal losses and their roles as mothers, spouses and sisters of desaparecidos (Jelin, 1994). Later, women sought connections with others who had lost their relatives during the dictatorships and began organising within the larger human rights movement. As a consequence, the motivation to mobilise for human rights was transformed from a personal to a public and political demand (ibid.).

In Honduras, women played a key role in political processes in the $1980 \mathrm{~s}$ and 1990s, protested against the disappearance of their relatives, organised demonstrations for peace and against US militarisation in the region and later, participated in truth and reconciliation commissions (Villars, 2001). Women of these movements launched many of the Honduran human rights organisations emerging during this period, such as COFADEH (Comité de Familiares de Detenidos Desaparecidos en Honduras), an organisation of relatives of the disappeared, CIPRODEH (Centro de Investigación $y$ Promoción de los Derechos Humanos), or Movimiento de mujeres por la Paz Visitación Padilla, a women's organisation for peace and against militarisation in the region.

Feminist movements in Latin America emerged early in these struggles against the authoritarian governments and were crucial actors in constructing democracies and mobilising against the atrocities of the military regimes (Vargas, 2010). Moreover, feminists across Latin America organised in regional encuentros, meetings, on feminism and human rights, and sought connections among women's groups and organisations across Latin America (S. E. Alvarez et al., 2008).

In Honduras, the first feminist organisations CEM-H (Centro de Estudios de la Mujer-Honduras) and CDM (Centro de Derechos de las Mujeres) emerged as a result of such regional exchange (Kennedy 2013) and were founded in the late 1980s and early 1990s. These organisations were organised locally, but were also vital in 
mainstreaming international women's rights issues into government institutions and establishing the National Women's Institute Instituto Nacional de le Mujer, INAM (Villars, 2001). Two decades later, these feminist organisations were also some of the key actors in a women's collective resistance movement against the coup in June 2009.

\section{Uniting spatial imaginaries in protests: the aftermath of the coup d'état}

Analysing the activists' perceptions and lived experiences - the institutional and societal challenges women interviewed experienced and the symbolic meanings and practices women used to respond to the coup - helps us understand how these experiences shaped and united different actors' spatial imaginaries.

In the days following the coup, the de facto government sought to restrict the upheaval by introducing a street curfew, using police and military forces to dissolve the protests and by controlling government-critical media. Women protesters reported physical abuse, harassment, rape as well as verbal abuse. Civil society's Truth Commission announced to the International Criminal Court (ICC) over 5000 human rights violations related to the protests (Comisión de Verdad, 2012).

When asked about challenges to women's rights in recent years, interviewees highlighted their distress over different forms of violence, both state violence and the everyday violence women faced in the streets, at home or at workplace. An activist from a feminist organisation in Tegucigalpa noted:

What we [women] are dealing with on a daily basis is state violence and violence caused by other criminal sectors, and it is basically everywhere. So we are in constant resistance against different aggressors.

To highlight these intersecting forms of violence after the coup, the movement Feministas en Resistencia created symbolic meanings with slogans such as 'Ni golpe de 
estado - ni golpe a las mujeres' (No coup d'état, no beating of women) to draw attention to both the rupture of the democratic process and the systemic societal violence against women. The interviews revealed that women with different social identities were able to embrace the feminist resistance movements' symbolic meanings because they reflected their lived experiences as women. A rural activist described her experience in the resistance movement:

I think we have grown a lot, as women. This coup made us mature. We have been continuously persecuted and threatened in the streets, some have lost their work, and many women have lost their children, others their own life but we have hope that we can change this country together with other organisations.

These statements exemplify how social movements in Latin America not only challenge political institutions but also make claims in cultural and social spaces (Dagnino 1998; Escobar 1998). They also reflect Alvarez' notion that feminists and other women's movements form collective (feminist) identities particularly when they are faced with a common adversary based on traditional or patriarchal values (Alvarez 2014).

In addition to such symbolic meanings, activists shaped their spatial imaginaries with collective human rights practices. Interviewees explained how they created prevention mechanisms against violence during protests, documented human rights violations committed by the authorities, and reported these to the international community (see also Ronderos, 2011). An activist of a human rights organisation in Tegucigalpa explained how those familiar with legal instruments taught others how to use the procedure habeas corpus (according to which a person can report an unlawful imprisonment or detention before a court) in cases of abuse.

Mirta Kennedy (2013), one of the founders of CEM-H and the feminist movement in Honduras, explained how feminist organisations experienced the upheavals' effects over two years later: 
Together with the social, popular movement our strategy is always a reaction to something. This is a profound crisis in our way to do politics. We have passed two decades doing feminist politics face to face with the state. That is, questioning the state, pressuring the state and the government, to have women's demands incorporated into legal, political and institutional documents. [...] But it is sure that with these governments, it is impossible.

This statement about feminists' spaces after the coup reveals the challenges the new political context in Honduras imposed because feminist organisations have generally proven to be fundamental to achieve equal rights and integrate women's rights into policy-making (Htun \& Weldon, 2012). Their resources were constrained because to both react to the political crisis and continue with feminist politics proved demanding. As a consequence, the organisations had to find alternative spaces and alliances in the aftermath of the overthrow.

As to feminist and broader women's movements' relationships in Honduras, Mirta Kennedy recounted that since the beginning of the $21^{\text {st }}$ century many women's and feminist organisations in urban areas had collaborated with women's movements in rural areas. During that period, feminists in various Latin American countries were engaged in gender and development projects (Verschuur, Guérin, \& Hélène, 2014). However, Mirta Kennedy explained that alliances between feminists and the broader women's movement strengthened notably after the political upheaval:

This was the scenario we found ourselves in at the coup d'état in 2009: Before the coup we had participated in four meetings on anti-militarisation, in several regional meetings with Mesoamerican women and Latin American women and with women in resistance, for example, at Social Forums. So we already had approached popular movements. But with the coup d'état and the political crisis, we drew even closer to these movements.

This account reveals how feminists began expanding their alliances due to the coup, 
which consequently shaped their understanding of space: Feminists, because of having connected with rural women during protests, expressed their solidarity with land struggles in regions such as Bajo Aguán or Río Blanco in north-eastern Honduras. While describing recent challenges to women's human rights, Merary, from a feminist university association, highlighted land struggles as part of women's and feminist movements' struggles:

[During protests] women are the most courageous, the ones who resist the most. It's because they [international companies] are invading our lands and we [women] are reclaiming what belongs to us. [...] When you look at the pictures after the coup, women were always in the front. So [it is] incredible how strong and courageous we [women] are.

This account illustrates how urban feminists' spatial imaginaries merged with those of rural women. Feminists helped to promote land struggles by acts of solidarity during demonstrations and calls for urgent action as well as on social media platforms. Wendy Cruz from the rural movement Via Campesina summarised their alliance with feminist organisations as follows:

In recent years, we [women] have stressed women's access to land as part of the women's movements' demands. That is, the feminist movement and the women's movement in this country have put land rights back onto their agenda; these rights are fundamental for women and for making structural changes in women's lives.

Drawing on such 'other feminisms' (Alvarez 2014) and advocating for gender-, indigenous peoples' and environmental issues, rural women in Honduras have recently played a pivotal role in making women human rights defenders' struggles visible and contributed to changing existing perceptions of women's role in society. Berta Cáceres of the rural indigenous movement Copinh, (Consejo Civico de Organizaciones Populares e Indigenas de Honduras), who was murdered in March 2015, was known 
for defending women's- and indigenous people's rights. Other rural organisations such as Via Campesina have actively promoted women's rights and gender justice in their work (see also Alvarez, 2014; Bhattacharjya et al 2013).

When asked about alliances with other actors, two interviewees from AMIR (Asociación de Mujeres Intibucanas Renovadas) highlighted feminist-, women's- and other human rights organisations' support. An AMIR activist stated:

Many organisations have supported us, and this has made us stronger. So we women feel encouraged to continue defending our rights, because we don't feel alone.

In addition to such symbolic support, the women interviewed stressed that organisations in urban areas had the necessary knowledge as well as social and material resources, for example to provide legal assistance and organise capacity-building on human rights.

Feminist and rural women's organisations have a long history of collaboration in Honduras. As the previous accounts demonstrate, these alliances were strengthened and both feminists' and rural women's perceptions of their spaces were shaped by the challenges to the interviewees that emerged during the political upheaval.

\section{Emergence of women's human rights discourses after the coup and women's collective identity as women human rights defenders}

Examining the interviewees' statements related to human rights deepens the understanding of the different factors that prompted a collective identity as women human rights defenders. The interviewees emphasised the gendered dimension of human rights violations during the protests. However, many of these women referred to human rights instead of (or in addition to) women's rights because they found the human rights framework a more powerful tool than the women's rights framework against the injustices of the government. Daysi Flores, coordinator of JASS 
International, reflected on the role of human rights discourses for the Network of Women Human Rights Defenders:

What we use the cause of human rights for is, for example, the sexual violence by the police and military that our colleagues on the streets experienced, because it was a violation of human rights. [...] If you leave it [sexual violence] only as [a matter of] women's rights, it lacks - not for us but in international discourse, including human rights defenders - it lacks validity.

The statement shows that activists framed women's rights violations as human rights violations in order to press claims to a broader target - and a broader scale. Local human rights organisations had long urged the international community to intervene in human rights violations in Honduras. However, the escalation of violence in June 2009 gained the attention of a broader audience. Consequently, on the recommendation of the international community in $2010^{4}$, the Ministry of Human Rights and Justice was established.

Since the coup, feminists and rural indigenous women have increasingly addressed human rights principles at regional and international platforms and organisations. They have been involved in formulating appeals directed to the InterAmerican Court for Human Rights, the United Nations Human Rights Commission, and the International Periodic Review of the United Nations, most recently in $2015 .^{5}$ As delegates, they have been able to address issues regarding violence against women in the common agenda with other human rights organisations. ${ }^{6}$ These appeals have addressed indigenous women activists' struggles in rural areas who, according to reports, are most exposed to violence exercised by private security, police and military forces (IM-Defensoras 2014). This corroborates the prevalent notion in social movement studies that activists mobilise beyond the local context in order to construct 
collective identities and to establish alliances with others (Alvarez 2014; Keck and Sikkink 1998).

While the human rights framework combined different spatial imaginaries of urban and rural activists, the women interviewed faced challenges in the broader resistance movement (see also Mendoza's work 2010a). Feminists interviewed expressed their distress over the patriarchal culture in physical spaces such as movement meetings and street protests. Merary, from a feminist student association, highlighted the patriarchal structures inside the social movements as a key challenge for women human rights defenders:

But of course, we [women] have to resist the system and our male compañeros who say they are revolutionaries and leftist, and we also have to organise against them.

Rachel, a feminist activist from the same focus group discussion had been part of the feminist movement since the 1980s and explained such structures were deeply embedded in the history of the leftist movements:

The women engaged in the struggles have always had to stand against their male compañeros from the left. So we have to be even stronger and we have to rise much higher than these men because we have to stand against all of them, in addition to others, who are from the same social class. In fact, it is a double resistance.

As empirical studies across the continent have shown, this has been a common development in many feminist- and women's movements in political processes (see also Jaquette, 2001, Alvarez 1998). Suyapa Martinez, the director of CEM-H, explained how women in the 1980s began realising they were subjects of rights and should organise as women for their own rights. She explained how after the coup in 2009 , women relived this situation - only now, they immediately began organising as women - and as 
women human rights defenders (Martinez, 2013).

The term 'human rights defender' was first launched by the United Nations in the Declaration on Human Rights Defenders in 1998. According to Bertha Oliva, founder of COFADEH, many human rights organisations in Honduras began using the term after 2005 when the European Union launched the Guideline on Human Rights Defenders (Oliva, 2013). However, various individuals and groups adopted the term during the political upheaval in Honduras. An activist of a local human rights organisation explained in an interview how the term spread after the coup:

When the coup d'état happened I was working in an organisation that had been working many years in this [field]. These [human rights] organisations started approaching activists and the term we used was 'human rights defenders', and we started saying to the people that, everyone who defends a right is a human rights defender. So, everyone realised that, in fact, they were defending a right.

Besides national and international arenas, the women interviewed also stressed their engagement in regional dialogues. Women's groups from Mexico, Honduras, El Salvador, and Guatemala founded the network Mesoamerican Initiative of Women Human Rights Defenders at a regional meeting in April 2010 in Oaxaca, Mexico. The network's aims were to report the violence that women human rights defenders were facing in the region and to protect them (IM Defensoras, 2011).

The national network in Honduras emerged primarily as a response to human rights abuses in the aftermath of the coup d'état. It has organised capacity-buildings on self-help and provided temporary shelter abroad for women persecuted for their activism, among others. Although not specifically feminist, the network draws on feminist ideas.

Members of the network discussed their role as women human rights defenders in a focus group discussion. When asked what being women human rights defenders 
meant to them, Carmen from a feminist students' association responded: 'First of all, it means pride. That we can protect people's lives, it is very gratifying to know we can do something.' Rachel from a feminist organisation replied: 'to be a women human rights defender means to be on the side of law. It means a responsibility.' Other responses revealed that the women felt responsible for defending others and, demonstrated they 'defended their right to defend', which reflects international discourses on human rights defenders whom the community perceives as supporting those who are not able to defend their own rights (UNHRC 2012). Moreover, the participants felt the network provided them protection because it raised their visibility in their communities. Martha, a rural community leader, summarised: 'I have always been a human rights defender, for 30 years. But with the network, I began identifying myself as one'.

These accounts reflect the activists' emotional connectedness with the network and its practices, which is essential for constructing collective identities (Bosco, 2006; Escobar, 2001; Polletta \& Jasper, 2001). On the one hand, women constructed their agency as women human rights defenders based on multiple identities, which shaped their perception of their own position in their communities. This corroborates the notion of Alexander and Mohanty (1997) on women's agency. On the other, these diverse identities and spatial imaginaries also shaped the network's ideology. This is especially noticeable in the network's broad definition of women human rights defenders (IMDefensoras 2015).

After the upheaval was over, the 'plurality of feminisms' (Alvarez, 1998, 2014) proved challenging because activists were simultaneously engaged in various struggles as diverse as sexual and reproductive rights, land rights and workers' rights (see also Mendoza, 2010a, 2010b). However, as the interviews revealed, the National Network of Women Human Rights Defenders can provide a framework for women's human rights 
struggles while taking into account their intersectional identities, similar to other women's human rights movements in Latin America such as the Madres de Plaza de Mayo. In the end, a collective identity as women human rights defenders emerged because activists expanded their spatial imaginaries - instead of remaining in their place-based struggles.

\section{Conclusion}

I argue in this study first, that women's collective action against the coup merged different spatial imaginaries, which were constructed through activists' perceptions and lived experiences of space. Feminists interviewed here, who had previously organised for women's rights in urban areas, embraced rural women's struggles for their lands. At the same time, rural women joined the feminist resistance movement against gender violence and the rupture of the democratic process and embraced feminist discourses and practices. These struggles were unified under the framework of human rights and social justice.

Second, the collective identity as women human rights defenders was central for the emergence of collective action. By framing their agency as human rights defenders, women activists were able to make claims on their government and the international community as defenders of human rights (Brysk, 2014). This is in line with Merry (2006), who argues that human rights discourses are accessible to a wide range of actors and can particularly assist women's movements, who in turn shape the network culture (Keck \& Sikkink, 1998).

Although women activists engaged in the broader discourse on human rights they still felt a strong identification as women. This collective identity was strengthened by the gendered violence women experienced during protests and the patriarchal culture they faced in the society and the broader resistance movement. As empirical studies 
have shown, this has been a common development in many women's movements in political processes (see also Jaquette, 2001, Alvarez 1998). However, activists were also able to draw on previous experience with leftist movements in the 1980 s and formed a collective resistance movement.

Women's collective action was maintained largely through feminist practices, resources and discourses because they had the necessary experience, knowledge and networks for advocacy work on multiple scales. The role of feminists continues to be crucial also in broader human rights activism in Honduras: Together with other human rights organisations they recently established the International Platform Against Impunity (Plataforma Internactional contra la Impunidad) - a branch of a network launched in Guatemala - as a control body of civil society to monitor human rights violations in Honduras.

Geographic analysis on women's collective action in changing political processes helps us understand how activists' perceptions and collective lived experiences can shape and expand activists' political spaces, which are based on certain political, geographic and historical contexts. Moreover, it shifts the focus from political opportunities in upheavals and, together with transnational feminist theories, helps to focus on women's active agency - the responses activists create to challenges - as the key factor for constructing such spaces.

Human rights framing is confronted with both ideological and institutional challenges. Human rights discourses opened new opportunities for action, but many interviewees felt they remained outside of political decision-making. Future research should firstly analyse how human rights strategies can best benefit women's movements, e.g. by comparing prevalent strategies. Secondly, research should assess 
the commonalities of women's spatial imaginaries based on human rights, in addition to analysing the place-based aspect of these struggles.

\section{Notes}

1. I draw here on Sonia Alvarez $(2000,2014)$ who uses the definitions feminist movements and broader women's movements (movimientos de mujeres) in the Latin American context but emphasises the multitude of feminisms and new forms of 'popular feminisms' that have taken shape among anti-neoliberal and anti-racist grassroots movements. The interviewees in this study used these same definitions.

2. Although the movement was called Feministas en Resistancia, it included groups and organisations that were not specifically feminist.

3. The research material includes interviews with activists from the Red Nacional de Defensoras Honduras (National Network of Women Human Rights Defenders Honduras), Centro de Estudios de la Mujer - Honduras (CEM-H), Centro de Derechos de las Mujeres (CDM), JASS International (coordination office in Honduras), Foro de Mujeres por la Vida, Movimiento Ambiental Santabarbarense (MAS), Consejo Civico de Organizaciones Populares e Indigenas de Honduras (Copinh), Movimiento de Mujeres por la Paz Visitación Padilla, Vía Campesina (Head office in Tegucigalpa) Asociación de Mujeres Intibucanas Renovadas (AMIR), Jueces para la Democracia, Comité de Familiares Detenidos en Honduras (COFADEH), as well as with the Ministry for Justice and Human Rights and the women's municipal office in San Pedro Sula. Some interviewees asked that their names and organisations not be mentioned.

4. The General Public Administration Law (Ley General de Administración Pública), Article 28 of 27 October 1986 legally established the Secretariat for Justice and Human Rights but the Secretariat was only formally established in the post-coup period in 2011. For international recommendations on national protection mechanisms, see e.g. the United Nations Special Rapporteur on the situation of human rights defenders, Margaret Sekaggya, on the conclusion of her official visit to Honduras, A/HRC/22/47/Add.1.

5. Feminist organisations report. Status of violence against women in Honduras by Centro de Derechos de la Mujer; Red Nacional de Defensoras de Derechos Humanos de Honduras; Foro de Mujeres por la Vida; JASS-Honduras and Centro de Estudios de la Mujer, 2014. 


\section{Acknowledgements}

I would like to thank Doris Wastl-Walter for her advice and insightful comments on this article. I am especially grateful to all those who shared their experiences and thoughts concerning this study in Honduras. Thanks also to Merita Jokela for her helpful suggestions on earlier versions of this paper. Finally, I thank the editor and three anonymous reviewers whose suggestions were invaluable.

\section{Notes on contributor}

Maaret Jokela-Pansini is PhD-candidate at the Institute of Geography at the University of Bern where she is also enrolled in the Graduate School of the Interdisciplinary Centre for Gender Studies. She has a MA degree (Magister Artium) in Political Sciences of the HumboldtUniversity of Berlin and University of Potsdam. She has worked in women's non-governmental organisations in Honduras and in Switzerland.

\section{References}

Alexander, J. M., \& Mohanty, C. T. (1997). Feminist Genealogies, Colonial Legacies, Democratic Futures. Thinking Gender. London: Routledge.

Alvarez, S. E. (1990). Engendering Democracy in Brazil: Women's Movements in Transition Politics. Princeton University Press.

Alvarez, S. E. (1998). Latin American Feminisms 'Go Global': Trends of the 1990s and Challenges for the New Millennium. In Cultures of Politics, Politics of Cultures: Re-visioning Latin American Social Movements. Boulder, Colorado: Westview Press, 293-324.

Alvarez, S. E. (2000). Translating the Global Effects of Transnational Organizing on Local Feminist Discourses and Practices in Latin America. Meridians, 1, 29-67. Alvarez, S. E. (2014). Ambivalent Engagements, Paradoxical Effects: Latin American Feminist and Women's Movements and/in/against Development. In C.

Verschuur, I. Guérin, \& H. Guétat-Bernard (Eds.), Under Development: Gender. London: Palgrave Macmillan.

Alvarez, S. E., Dagnino, E., \& Escobar, A. (1998). The Cultural and the Political in Latin American Social Movements. In Cultures of Politics, Politics of Cultures: 
Re-visioning Latin American Social Movements. Boulder, Colorado: Westview Press.

Alvarez, S. E., Friedman, E., Beckman, E., Maylei, B., Stoltz, C. N., Lebon, N., Ríos Tobar, M. (2008). Encountering Latin American and Caribbean Feminisms.

Signs: Journal of Women in Culture and Society, 28(2), 537-579.

Arnson, C. J., \& Olson, E. L. (2011). Organized Crime in Central America. The Northern Triangle. Woodrow Wilson Center Reports on the Americas \#29.

Washington DC, available from http://www.wilsoncenter.org/sites/default/files/LAP_single_page.pdf .

Atkinson, R., \& Flint, J. (2001). Accessing Hidden and Hard-to-Reach Populations:

Snowball Research Strategies. Social Research Update, 33(1), 1-4.

Baldez, L. (2003). Womens Movements and Democratic Transition in Chile, Brazil, East Germany and Poland. Comparative Politics, 35(3), 253-272.

Basu, A. (2000). Globalization of the Local/Localization of the Global. Mapping Transnational Women's Movements. Meridians, 1(1), 68-84.

Bhattacharjya, M., Birchall, J., Caro, P., Kelleher, D., \& Sahasranaman, V. (2013). Why Gender Matters in Activism: Feminism and Social Justice Movements. Gender \& Development, 21(2), 277-293.

Bosco, F. (2006). The Madres de Plaza de Mayo and Three Decades of Human Rights Activism: Embeddedness, Emotions and Social Movements. Annals of the Association of American Geographers, 96(2), 342-365.

Brenneman, R. (2014). Wrestling the Devil. Latin American Research Review, 49, 112 128.

Brondo, K. V. (2007). Land Loss and Garifuna Women's Activism on Honduras' North Coast. Journal of International Women's Studies, 9(1), 99-116.

Brown, M., \& Staeheli, L. (2003). ‘Are We There Yet?’ Feminist Political Geographies. Gender, Place \& Culture, 10(3), 247-255.

Brysk, A. (2014). Human Rights Defenders and Activism. In The SAGE Handbook of Human Rights: Two Volume Set, Volume 1, edited by A. Mihr \& M. Gibney. London: SAGE Publications, 340-351.

Chinchilla, N. S. (1994). Feminism, Revolution, and Democratic Transitions in Nicaragua. In The women's movement in Latin America. Participation and 
democracy, edited by J. S. Jaquette. Boulder, Colorado: Westview Press, 177198.

Coe, A.-B. (2015). 'I Am Not Just a Feminist Eight Hours a Day' Youth Gender Justice Activism in Ecuador and Peru. Gender \& Society, 29(6), 888-913.

Comisión de Verdad. (2012). La voz más autorizada es la de las víctimas. Informe de la Comisión de Verdad (October 2012). Tegucigalpa.

Crenshaw, K. (1991). Mapping the Margins: Intersectionality, Identity Politics, and Violence Against Women of Color. Stanford Law Review, 43(6), 1241-1299.

Dagnino, E. (1998). Culture, Citizenship and Democracy: Changing Discourses and Practices of the Latin American Left. In Cultures of Politics, Politics of Cultures: Re-visioning Latin American Social Movements, edited by S. Alvarez, E. Dagnino, \& A. Escobar, 33-63.

Escobar, A. (1998). Whose Knowledge, Whose Nature? Biodiversity, Conservation, and the Political Ecology of Social Movements. Journal of Political Ecology, 5, $53-82$.

Escobar, A. (2001). Culture Sits in Places: Reflections on Globalism and Subaltern Strategies of Localization. Political Geography, 20(2), 139-174.

Espina, G. (2009). Feminist Activism in a Changing Political Context. In Feminist Agendas and Democracy in Latin America, edited by J. Jaquette. Durham: Duke University Press, 65-82.

Fairglough, N., \& Wodak, R. (1997). Critical Discourse analysis. In Discourse Studies: A Multidisciplinary Introduction, edited by T. van Dijk, London: SAGE Publications, 258-284.

Glenn, E. N. (2002). Unequal Freedom. How Race and Gender Shaped American Citizenship and Labor. Cambridge, MA: Harvard University Press.

Hassim, S. (2006). Women's Organizations and Democracy in South Africa. Contesting Authority. Wisconsin: The University of Wisconsin Press.

Holloway, J., \& Pelaez, E. (1998). Zapatista!: Reinventing Revolution in Mexico. London: Pluto Press.

Htun, M., \& Weldon, S. L. (2012). The Civic Origins of Progressive Policy Change: Combating Violence against Women in Global Perspective, 1975-2005. American Political Science Review, 106(03), 548-569. 
IM Defensoras (2011). Violencia contra Defensoras de Derechos Humanos en Mesoamérica. Un diagnóstico en construcción.

IM Defensoras (2015). Violence against Women Human Rights Defenders in Mesoamerica 2012-2014: Report.

Jaquette, J. S. (2001). Regional differences and contrasting views. Journal of Democracy, 12(3), 111-125.

Jaquette, J. S. (2009). Feminist Agendas and Democracy in Latin America. Durham: Duke University Press.

Jasper, J. M. (2014). Feeling-Thinking: Emotions as Central to Culture. In Conceptualising Culture in Social Movement Research, edited by B. Baumgarten, P. Daphi, \& P. Ullrich. London: Palgrave Macmillan, 23-44.

Jelin, E. (1994). Ante, de, en, y? Mujeres y derechos humanos. América Latina Hoy, 9, $7-23$.

Keck, M., \& Sikkink, K. (1998). Activists beyond Borders. Ithaca, New York: Cornell University.

Kennedy, M. (2013). Interview by author on 29.1.2013.

Kriesi, H. (2007). Political Context and Opportunity. In The Blackwell Companion to Social Movements, edited by David A. Snow, Sarah A. Soule and Hanspeter Kriesi, 67-90.

Lefebvre, H. (1991). The Production of Space (translated by D. Nicholson-Smith), Cambridge: Blackwell.

Martin, D. G., \& Miller, B. (2003). Space and Contentious Politics. Mobilization: An International Journal, 8(2), 143-156.

Martinez, S. (2013). Interview by author on 21.1.2013.

Massey, D. B. (1994). Space, Place and Gender. Minneapolis: University of Minnesota Press.

McAdam, D., McCarthy, J. D., \& Zald, M. N. (1996). Comparative Perspectives on Social Movements. Political Opportunities, Mobilizing Structures, and Cultural Framings. Cambridge Studies in Comparative Politics. Cambridge: Cambridge University Press.

McCall, L. (2005). The Complexity of Intersectionality. Signs: Journal of Women in Culture and Society, 30(3), 1771-1800. 
Melucci, A. (1985). The Symbolic Challenge of Contemporary Movements. Social Research, 52(4), 789-816.

Mendoza, B. (2002). Transnational Feminisms in Question. Feminist Theory, 3(3), 295314.

Mendoza, B. (2010a). El neoconstitucionalismo de la izquierda latinoamericana: el caso de Honduras. Revista Centroamericana de Ciencias Sociales, 7 (2), 5-22.

Mendoza, B. (2010b). Reflexiones teoricas para un movimiento feminista de la noviolencia. Tegucigalpa: Centro de Estudios de la Mujer-Honduras.

Merry, S. E. (2006a). Human Rights and Gender Violence: Translating International Law into Local Justice. Chicago: The University of Chicago Press.

Merry, S. E. (2006b). Transnational Human Rights and Local Activism: Mapping the Middle. American Anthropologist, 108(1), 38-51.

Merry, S. E., \& Levitt, P. (2010). Law From Below: Women's Human Rights and Social Movements in New York City. Law \& Society, 44(1), 101-128.

Meyer, D. S., \& Staggenborg, S. (1996). Movements, Countermovements, and the Structure of Political Opportunity. American Journal of Sociology, 101(6), 1628-1660.

Mohanty, C. T. (2003a). Feminism without Borders: Decolonizing Theory, Practicing Solidarity. Durham: Duke University Press.

Mohanty, C. T. (2003b). 'Under Western Eyes' Revisited: Feminist Solidarity through Anticapitalist Struggles. Signs: Journal of Women in Culture and Society, 28(2), $499-535$.

Mollett, S. (2010). Esta listo (Are you ready)? Gender, Race and Land Registration in the Río Plátano Biosphere Reserve. Gender, Place \& Culture, 17(3), 357-375.

Mollett, S., \& Faria, C. (2013). Messing with Gender in Feminist Political Ecology. Geoforum, 45, 116-125.

Molyneux, M. (1998). Analysing Women's Movements. Development and Change, 29(2), 219-245.

Naples, N. A. (2003). Feminism and Method: Ethnography, Discourse Analysis, and Activist Research. London: Routledge.

Noonan, R. (1995). Women against the State: Political Ppportunities and Collective Action Frames in Chile's Transition to Democracy. Sociological Forum, 10(1), $81-111$. 
Okazawa-Rey, M. (2009). Solidarity with Palestinian Women: Notes from a Japanese Black U.S. Feminist. In Activist Scholarship. Antiracism, Feminism, and Social Change, edited by J. Sudbury \& M. Okazawa-Rey. Boulder: Paradigm Publishers, 205-223.

Oliva, B. (2013). Interview by author on 21.11.2013.

Polletta, F., \& Jasper, J. M. (2001). Collective Identity and Social Movements. Annual Review of Sociology, 27, 283-305.

Pratt, G. (2000). Research performances. Environment and Planning D: Society and Space, 18(5), 639-651.

Ronderos, K. (2011). Poverty Reduction, Political Violence and Women's Rights in Honduras. Community Development Journal, 46(3), 315-326.

Routledge, P. (2009). Transnational Resistance: Global Justice Networks and Spaces of Convergence. Geography Compass, 3, 1881-1901.

Rupp, L. J., \& Taylor, V. (1999). Forging Feminist Identity in an International Movement: A Collective Identity Approach to Twentieth-Century Feminism. Signs: Journal of Women in Culture and Society, 24(2), 363-386.

Sosa Iglesias, J. E. (2014). Honduras: Entre criminalidad, enfrentamiento mediático, protesta social y resultados electorales cuestionados. Revista de Ciencia Politica, 34(1), 203-219.

Staggenborg, S. (1998). Social Movement Communities and Cycles of Protest: The Emergence and Maintenance of a Local Women's movement. Social Problems, 45(2), 180-204.

Staggenborg, S. (2001). Beyond Culture versus Politics: A Case Study of a Local Women's Movement. Gender \& Society, 15(4), 507-530.

Staheli, L. A., \& Lawson, V. A. (1995). Feminism, Praxis, and Human Geography. Geographical Analysis, 27(4), 321-338.

Sundberg, J. (2004). Identities in the Making: Conservation, Gender and Race in the Maya Biosphere Reserve, Guatemala. Gender, Place \& Culture, 11(1), 43-66. Sundberg, J. (2007). Researching Resistance in a Time of Neoliberal Entanglements. In Neoliberal Environments: False Promises and Unnatural Consequences, edited by N. Heynen, J. McCarthy, S. Prudham \& P. Robbins. New York: Routledge, 269-272. 
Taylor, V., \& Whittier, N. E. (1992). Collective Identity in Social Movement Communities: Lesbian Feminist Mobilization. In Frontiers in Social Movement Theory, edited by A. Morris and C. Mueller. New Haven: Yale University Press, 104-130.

Tilly, C. (2004). Contentious choices. Theory and Society, 33, 473-481.

UNHRC (2010). Report of the Special Rapporteur on the Situation of Human Rights Defenders, A/HRC/16/44 (20 December 2010), available from www2.ohchr.org/english/bodies/hrcouncil/docs/16session/A-HRC-16-44.pdf.

UNHRC (2012). Statement of the United Nations Special Rapporteur on the Situation of Human Rights Defenders, Margaret Sekaggya, on the Conclusion of Her Official visit to Honduras (February 14, 2012) available from http://www.ohchr.org/Documents/HRBodies/HRCouncil/RegularSession/Sessio n22/AHRC2247Add.1_English.pdf.

UNODC (2013). World Drug Report 2013. New York: United Nations Office on Drugs and Crime.

Vargas, V. (2001). The Struggle by Latin American Feminisms for Rights and Autonomy. In Gender and the Politics of Rights and Democracy in Latin America, edited by M. Molineux \& N. Craske, London: Palgrave Macmillan, $199-222$.

Vargas, V. (2010). Constructing New Democratic Paradigms for Global Democracy. In Women's activism in Latin America and the Caribbean. Engendering Social Justice, Democratizing Citizenship, edited by E. Maier \& N. Lebon. New Brunswick, NJ: Rutgers University Press, 319-334.

Verschuur, C., Guérin, I., \& Hélène, G.-B. (2014). Under Development: Gender. London: Palgrave Macmillan.

Villars, R. (2001). Para la casa mas que para el mundo: Sufragismo y feminismo en la historia de Honduras. Tegucigalpa: Editorial Guaymuras.

Wodak, R. (2001). What CDA is About - a Summary of iIts History, Important Concepts and Its Developments. In Methods of Critical Discourse Analysis, edited by R. Wodak and M. Meyer. London: Sage Publications, 1-18.

Wolford, W. (2004). This Land is Ours Now: Spatial Imaginaries and the Struggle for Land in Brazil. Annals of the Association of American Geographers, 94(2), $409-424$. 
Wright, M. W. (1997). Crossing the Factory Frontier: Gender, Place and Power in the Mexican Maquiladora. Antipode, 29(3), 278-302.

Wright, M. W. (2004). From Protests to Politics: Sex Work, Women's Worth, and Ciudad Juárez Modernity. Annals of the Association of American Geographers, 94(2), 369-386.

Wright, M. W. (2005). Paradoxes, Protests and the Mujeres de Negro of Northern Mexico. Gender, Place \& Culture, 12, 277-292. 